\title{
STANDARDIZATION OF THE SULPHUR BOILING POINT
}

\author{
By E. F. Mueller and H. A. Burgess
}

\section{CONTENTS}

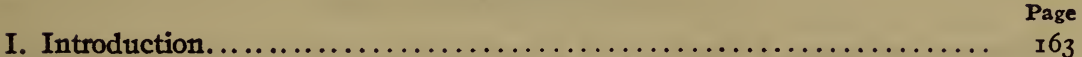

II. Apparatus used..................................... I66

III. Description of experiments.......................... I68

r. Comparison of radiation shields $\ldots \ldots \ldots \ldots \ldots \ldots \ldots \ldots \ldots \ldots, \quad$ I68

2. Influence of type of sulphur boiling apparatus............. I 77

3. Purity of sulphur.............................. I 79

4. The relation between the vapor pressure of sulphur and tem-

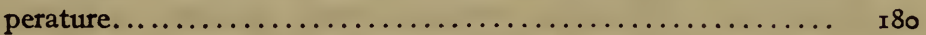

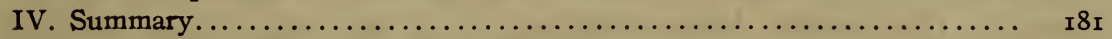

Appendix.-Proposed standardization of the sulphur boiling point......... I8 83

\section{INTRODUCTION}

The sulphur boiling point occupies a position of unusual importance among the thermometric fixed points on account of the care and accuracy with which its temperature has been determined, the precision with which this temperature may be reproduced, but most of all on account of the very general practice of using it to determine one of the fundamental calibration constants of the platinum resistance thermometer, which serves as the most precise and convenient means now available for defining the temperature scale in the range $-50^{\circ}$ to $+500^{\circ} \mathrm{C}$. The best measurements available are insufficient to show that the scale so defined differs from the thermodynamic scale in any part of this range.

The results of the best determinations of the temperature of the sulphur boiling point on the thermodynamic scale are summarized in Table I which, with the exception of the last entry, is abbreviated from that given by Day and Sosman. ${ }^{1}$

1 Am. Jour. of Science IV, 33, p. 530; 1912. Also Jour. Wash. Acad. of Sciences, 2, p. 174; 1912. Also Ann. d. Physik IV, 38, p. 865; 1912. 
TABLE 1.-Determinations of the Temperature of the Sulphur Boiling Point

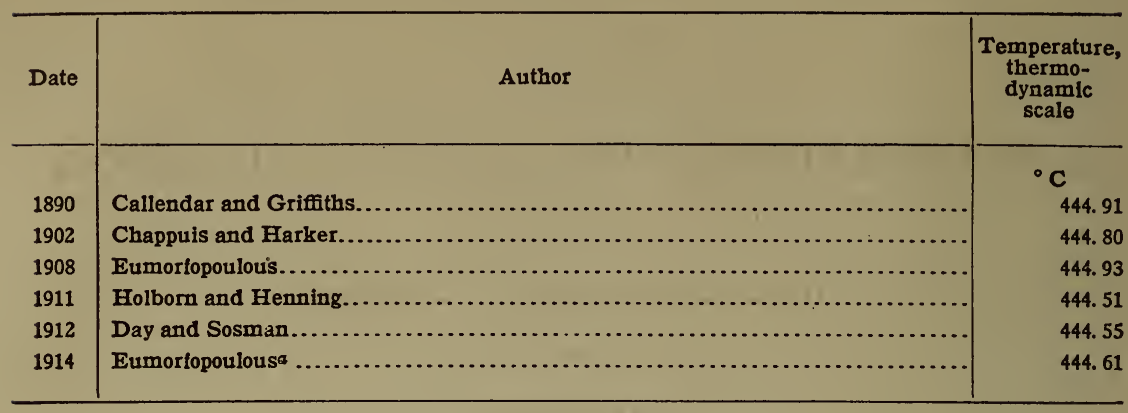

a Proc. Roy. Soc. London, A, 90, p. 189; 1914.

From the data of Table I it appears that any value which may be selected as representing the temperature of the sulphur boiling point may be in error by $0.1^{\circ}$ or even $0.2^{\circ}$, and that fixing this point to a few hundredths of a degree, which is the precision attainable with a resistance thermometer, is at present a matter of definition. On the grounds that greater weight should be given to the newer determinations, but that the value is not known better than $0.1^{\circ}$, there is a choice as to whether $444.5^{\circ}$ or $444.6^{\circ}$ shall be selected. As none of the values is as low as $444.5^{\circ}$ and all the older values are decidedly above this, the Bureau has adopted the value $444 \cdot 6^{\circ}$. For the purpose of defining the scale of the platinum resistance thermometer, the temperature of the sulphur boiling point under standard atmospheric pressure is taken by definition as $444.60^{\circ}$.

An analogous procedure has been found useful in defining the electric units for practical use. Thus the ohm for practical use is defined as the resistance of a column of mercury the length of which is specified to an accuracy of I part in 100000 , while it is known that the ohm so defined may differ from the cgs unit by perhaps I part in 3000 .

Having decided upon the value to be used for the temperature of the sulphur boiling point, it is necessary to define the experimental conditions so as to make the temperature reproducible with the highest attainable precision in order that the temperature scale defined by the platinum resistance thermometer may also be as definite and reproducible as possible.

The effect of the experimental conditions, particularly as regards shielding of the thermometer, had been investigated by Callendar and Griffiths, ${ }^{2}$ Waidner and G: K. Burgess, ${ }^{3}$ and by

2 Phil. Trans., A, 182, p. 143; 189r.

Bull. Bureau of Standards, 6, p. 189; 1910 (B. S. Scientific Paper No. 124). 
others. More recently Meissner ${ }^{4}$ reported further experiments which showed that the temperature assumed by a resistance thermometer in the sulphur vapor depended upon the reflecting power of the interior of the shield. His work raised some doubt as to the adequacy of the older work, but was incomplete in some respects. It did not indicate, for example, to what extent the effectiveness of a given shield depended upon the nature of the material used for the protecting tube of the thermometer. Waidner and Burgess had also investigated the temperatures in various types of boiling apparatus. Apparently there has been no investigation of the effect of impurities in the sulphur upon the observed boiling point. The variation of temperature with pressure has been experimentally investigated by Holborn and Henning, ${ }^{5}$ and by Harker and Sexton. ${ }^{6}$

As the result of these investigations the method of using the sulphur boiling point has, to a certain extent, become standardized. It has become the common practice to use a boiling tube of glass or like material about $5 \mathrm{~cm}$ in diameter. Also it is generally recognized that the source and manner of heating should be so controlled as not to superheat the vapor, and that the thermometer must be suitably protected from the effect of loss of heat by radiation or otherwise, as without such protection the observed value may be a degree or more in error.

The manner of observing these avowedly necessary precautions has differed considerably with different experimenters, apparently depending upon convenience or personal preferences. None but glass or similar boiling tubes have been used since Regnault's time. Both gas and electricity have been used for heating, and of either type of apparatus there have been numerous designs. The greatest variation has, however, occurred in the type of radiation shield employed on the thermometer, whether gas, mercurial, or electrical thermometers were used. These shields have been of many shapes and sizes, and have been constructed of glass and platinum, iron, asbestos, and aluminum. The tubes incasing the platinum thermometers have been either glass, quartz, or porcelain.

It is the purpose of this paper to present further evidence on the effect of these experimental conditions with the object of making this evidence sufficiently complete to serve as a basis for

- Annalen d Physik IV, 39, p. r230; 1912.

- Annalen d Phsyik IV, 26, p. 859, Ig08; IV, 35, p. 772, 1911.

- Report British Association, p. 621, 1908. 
standard specifications for the use of the sulphur boiling point as a calibration temperature. The work was therefore planned so as to supplement and complete, in so far as possible, the work of previous investigators.

\section{APPARATUS USED}

The greater part of the work was done with a gas-heated apparatus shown in Fig. $\mathbf{r}$. This apparatus is a development of the gas-heated apparatus which has been used regularly at the Bureau for some years. ${ }^{7} \quad$ The improvements are mainly in certain details which give greater ease and convenience in manipulation. The new apparatus was made to accommodate two lengths of boiling tubes of about $45 \mathrm{~cm}$ and $70 \mathrm{~cm}$, respectively, both of which were used, and the insulating jacket was made in two sections to suit the two lengths. The source of heat was a Méker blast burner, the flame of which played against a heavy ribbed iron casting containing a well about $7 \mathrm{~cm}$ deep in which the lower end of the boiling tube rested. The liquid sulphur surface was kept about $5 \mathrm{~cm}$ above the top of this casting to prevent superheating of the vapor. The thermometer was held in a specially designed clamp which could be opened or closed quickly by one motion and which when once set in position held the thermometer always in alignment and concentric with the boiling tube. This clamp was carried on a rack and pinion carriage which moved up and down on the main vertical supporting rod of the apparatus, which was equipped with a scale for reading directly the position of the thermometer coil inside the boiling tube. The heat insulation was very efficient and the sulphur could be brought to boiling sufficiently for an observation in less than an hour after starting.

Both glass and fused quartz tubes were used, the latter provided with a narrow fused-in window of transparent quartz near the top through which the line of condensation could be observed. Ample opening was left in the cover of the boiling tube for equalization of pressure inside and outside the tube.

The apparatus is so arranged that the ribbed casting and the burner can be removed and an electric heater substituted. This heater consists of a porcelain tube, $15 \mathrm{~cm}$ long, having an inside diameter 5 to ro $\mathrm{mm}$ larger than that of the boiling tubes used. The heating coil is of nichrome tape wound on the porcelain. The

7 Waidner and Burgess, loc. cit., p. 187. 
Scientific Papers of the Bureau of Standards, Vol. 15
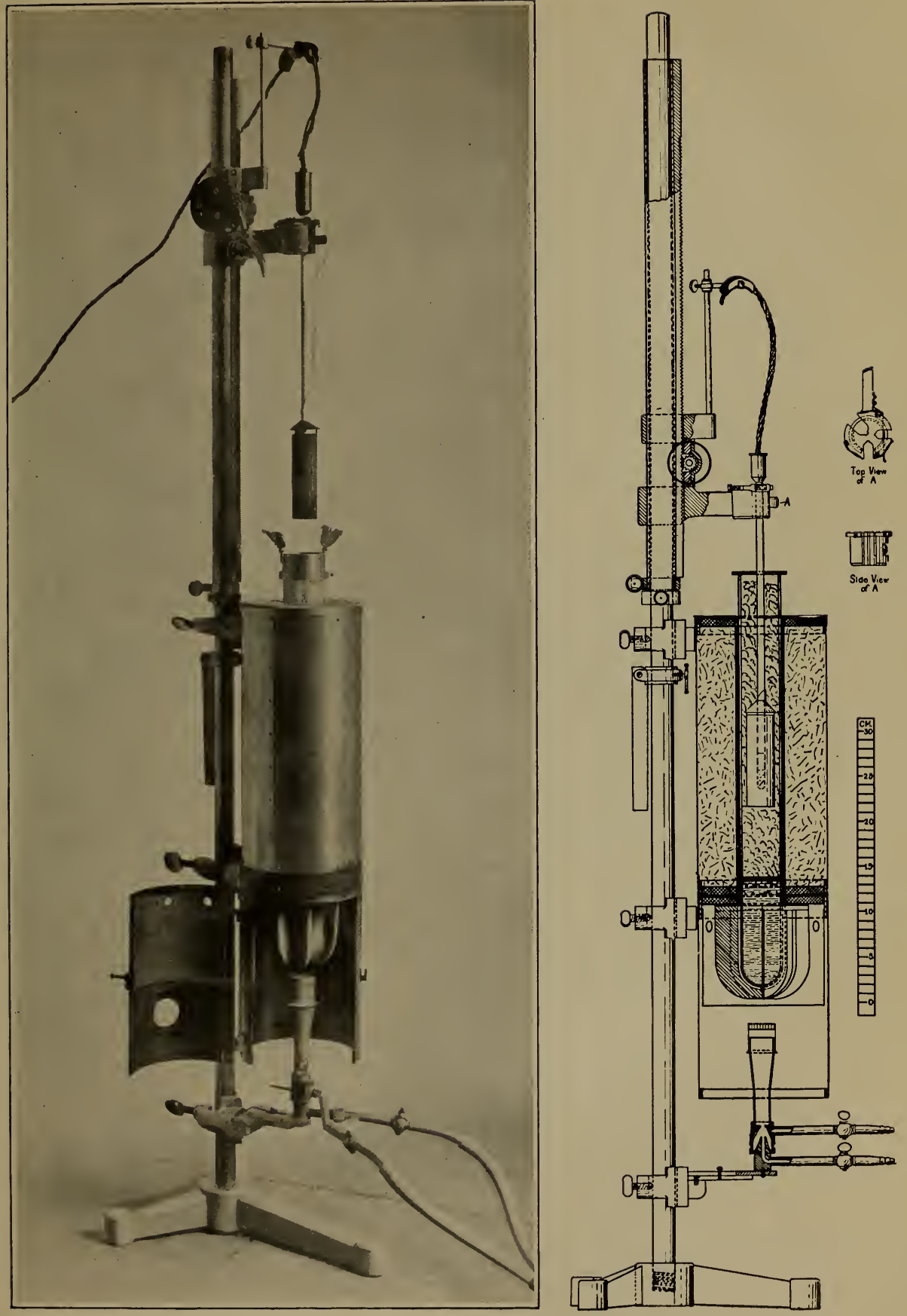

FIG. I.-Gas-heated sulphur boiling apparatus 
top of this porcelain tube occupies the same position as the top of the ribbed casting, and the heating coil covers the upper $8 \mathrm{~cm}$ of it. The boiling tube extends into this tube about $7 \mathrm{~cm}$, resting on a cushion of soft asbestos.

A heater of this type had been improvised for some special experiments and proved so satisfactory that the heater described above was built and has superseded the gas heater.

The resistance thermometers used were made in the usual form with cylindrical coils and were inclosed in glass or porcelain tubes. Some of the thermometers were provided with interchangeable glass and porcelain tubes. The coils were of the strain-free type ${ }^{8}$ and the leads were so fastened to the supporting mica strips that any strain on the leads could not be communicated to the coil. The connections were of the potential terminal type. Resistances were measured with a mercury contact Wheatstone bridge together with a commutator according to the method previously described. ${ }^{\circ}$

The constants of the thermometers as determined at various times are given in Table 2 where $R_{o}$ is the resistance in melting ice, and $F$ the increase in resistance on heating from $0^{\circ}$ to $100^{\circ} \mathrm{C}$. The measuring currents used in thermometers $\mathrm{C}_{28}, \mathrm{C}_{27}$, and $\mathrm{C}_{28}$ were 4 milliamperes and the current used in $\mathrm{C}_{22}$ was 2 milliamperes.

The heating effect of the measuring current used for $\mathrm{C}_{26}, \mathrm{C}_{27}$, and $\mathrm{C}_{28}$ was about $0^{\circ} .003$, and for $\mathrm{C}_{22}$ was about $0^{\circ} .002$ in both ice and steam. It is known from the work of Waidner and Burgess and of Smith ${ }^{10}$ that for thermometers of this type the heating effect of the measuring current, maintained constant, is of the same order of magnitude at $45^{\circ}$ as at $0^{\circ}$ and at $100^{\circ}$.

The coils of $\mathrm{C}_{26}, \mathrm{C}_{27}$, and $\mathrm{C}_{28}$ are about $4.5 \mathrm{~cm}$ long and the protecting tubes are $5 \mathrm{~mm}$ internal and $7 \mathrm{~mm}$ external diameter. The coil of $\mathrm{C}_{22}$ is about $8 \mathrm{~cm}$ long and the protecting tube is $8 \mathrm{~mm}$ internal and ro $\mathrm{mm}$ external diameter.

A Fuess siphon-type barometer, which could be read to an accuracy of 0.02 to $0.04 \mathrm{~mm}$, was used for the measurements of atmospheric pressure. All pressures were expressed in the equivalent millimeters of mercury at $0^{\circ}$ and under standard gravity $(g=980.665)$.

8 Waidner and Burgess, loc. cit., p. 115 .

- Mueller, this Bulletin, 13, p. 547; 1916 (B. S. Scientific Paper No. 288).

10 F. E. Smith, Phil. Mag., VI, 24, p. 545; 1912. 
TABLE 2.-Resistances at $0{ }^{\circ} \mathrm{C}\left(R_{\mathrm{o}}\right)$ and Fundamental Intervals $(F)$ of Thermometers Used

\begin{tabular}{|c|c|c|c|c|c|c|c|c|}
\hline \multirow{2}{*}{ Date. } & \multicolumn{2}{|c|}{$\mathrm{C}_{26}$} & \multicolumn{2}{|c|}{$\mathrm{C}_{27}$} & \multicolumn{2}{|c|}{$\mathrm{C}_{28}$} & \multicolumn{2}{|c|}{$\mathrm{C}_{22}$} \\
\hline & $R_{\mathbf{0}}$ & $F$ & $R_{\mathrm{o}}$ & $F$ & $R$ & $F$ & $R_{0}$ & $F$ \\
\hline July $19,1915$. & Ohms & Ohm & Ohms & Ohm & $\begin{array}{l}\text { Ohms } \\
2.53727\end{array}$ & $\begin{array}{l}\text { Ohm } \\
0.99364\end{array}$ & $\begin{array}{c}\text { Ohms } \\
\ldots \ldots \ldots . .\end{array}$ & Ohms \\
\hline Oct. $23,1915$. . & 2. 53788 & $0.9924_{3}$ & 2. 54871 & $0.9983_{3}$ & ……. & & & \\
\hline Nov. 2, 1915. . & 2. 53785 & & ........... & .......... & ............ & & & \\
\hline Nov. 4, 1915. . & 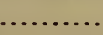 & & 2. 54867 & & 2. 53725 & & & \\
\hline Nov. $12,1915$. & & & 2. 54869 & & $\cdots$ & & & \\
\hline Nov. 23, 1915. & & & 2. 54871 & & & & & \\
\hline Jan. $4,1916 \ldots$ & & $\cdots$ & 2. 54869 & ..... & ...... & & & \\
\hline Jan. 24, 1916.. & 2. 53785 & .99248 & 2. 54870 & $.9983_{2}$ & 2.53725 & .99368 & & \\
\hline Feb. 28, 1916.. & & & & & & & 25.5472 & 9. $987 \mathrm{~g}$ \\
\hline Mar. 9, 1916.. & & & 2. 54870 & & 2. 53726 & & & \\
\hline Mar. 28, 1916. & & & ........... & & ........... & & 25,5476 & 9.9876 \\
\hline Apr. 5, 1916... & & & .......... & & & & 25.5476 & 9. $987_{8}$ \\
\hline May 11, 1916.. & & & 2. 54870 & & . & & 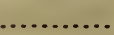 & \\
\hline May 12, 1916. & & & $\cdots$ & & 2. 53724 & & & \\
\hline May $19,1916 .$. & & & & & & & $a_{25.5461}$ & \\
\hline May 26, 1916. . & & & 2.54869 & & & & & \\
\hline June 20, 1916. & & & 2. 54868 & & & & & \\
\hline June 23, 1916. & & & & & & & $a_{25.5499}$ & \\
\hline
\end{tabular}

a The comparatively large changes noted in this thermometer were not satisfactorily explained. Fortunately, they were without effect on any of the results obtained with it in this investigation.

\section{DESCRIPTION OF EXPERIMENTS}

\section{COMPARISON OF RADIATION SHIELDS}

Some of the shields used are illustrated in Fig. 2. The openings at the tops of the shields were made to fit the thermometer tubes closely. All the shields were made so that any openings in the shields were at least $2 \mathrm{~cm}$ above or below the coils of the thermometers.

For the comparative tests a thermometer, inclosed in its shield, was inserted into the sulphur vapor, and the resistance and corresponding barometric pressure were observed for four different depths of immersion of the thermometer, with its attached shield, these positions being such that the bottom of the shield was 6,8 , Io, and $12 \mathrm{~cm}$, respectively, above the surface of the liquid sulphur. Time was allowed for the establishment of equilibrium before each reading. In most of the experiments the changes of temperature observed accompanying the above displacements were, after changes in barometric pressure had been allowed for, within the limits of observational error (less than $0.02^{\circ}$ ), and this constancy was a valuable indication of suitable experimental conditions. 
Where such constancy was not observed the fact is noted in the tables. In all cases the result given in the tables is the one obtained from the readings at the $8 \mathrm{~cm}$ height.

The temperature of the vapor was deduced from the barometric pressure by use of the formula,

$$
t=444 .{ }^{\circ} 6+0.0910(p-760)-0.000049(p-760)^{2}
$$

which is based on data given later in this paper.

The comparison of the temperatures as observed with the resistance thermometer is made most conveniently by computing for

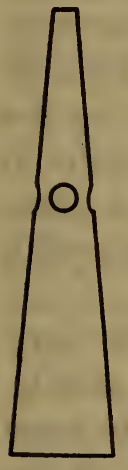

Cone

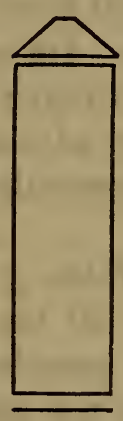

Umbrella, cylinder, and disk

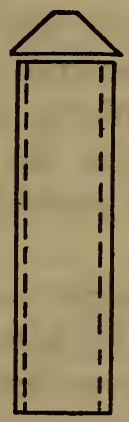

Umbrella and double cylinder

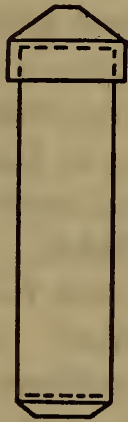

Complete aluminum shield

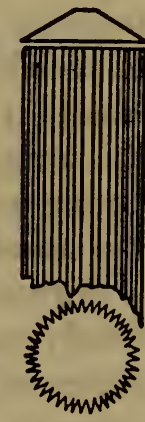

Corrugated aluminum shield

FIG. 2.-Types of radiation shields

each observation the platinum temperature, designated $p t_{760}$, corresponding to standard barometric pressure.

By differentiating the Callendar formula

$$
t-p t=\delta\left(\frac{t}{\mathrm{IOO}}-\mathrm{I}\right) \frac{t}{\mathrm{IOO}} \text { where } p t=\left(\frac{R_{\mathrm{t}}-R_{\mathrm{o}}}{F}\right) \mathrm{roO}
$$

a relation

$$
d p t=\left(\mathrm{I}+\frac{\delta}{\mathrm{IOO}}-\frac{2 \delta t}{\mathrm{IOO}^{2}}\right) d t
$$

is found, which for values of $\delta=\mathrm{I}, 495$ and $t=444^{\circ}$ becomes

$$
\Delta p t=0.882 \Delta t
$$

This equation is applicable for the entire range of barometric pressures and for all the values of $\delta$ occurring in this series of experiments. 
The comparative data for various shields, all obtained in the gas-heated boiling apparatus, are assembled in Table 3 , classified according to kind of shield used. The table shows the date of the observation, the number of the thermometer, the material of the thermometer protecting tube, the type of shield used, the platinum temperature corresponding to standard barometric pressure as calculated from each observation, and the amount by which this is lower than the average platinum temperature found with all the shields which were adequate.

The experimental work was planned and carried out so that all results could be referred to a standard type of shield-that is, during each day's observations an iron cone or an iron cylinder with umbrella was used at least once-and it would have been possible to present the data in this comparative form. On assembling the results it appeared that it would be simpler to give the results in the form shown in Table 3 with the further advantage of eliminating accidental errors in the individual observations made with the standard shields.

Fortunately, the facts brought out in Table 3 can be very briefly summarized. It will be noted that all the iron shields, either with or without the lower disk, gave practically the same value of $p t_{780}$ for any one thermometer, and the mean of all the values obtained with these shields may be considered the standard value. Since it is evident that no shield can cause the thermometer to assume a temperature higher than that of the vapor, it follows that low values of $p t_{760}$ indicate inadequate shielding. All of the data substantiate Meissner's view that a shield, the inner surface of which is a good reflector, will be ineffective. This is now shown to be true whether the thermometer is inclosed in glass or in porcelain. Thus the iron shields, the Callendar Griffiths shield, graphite cylinder, asbestos cone, an aluminum shield, blackened inside, are all effective. Even an aluminum cylinder, with the walls sharply corrugated, forming a series of wedges, and which is therefore a good radiator, was as effective as the other shields.

A complete aluminum shield was nearly realized in a cylindrical shield with overhanging umbrella and the lower edge of the cylinder extending below the lower disk and curving inward, so that all direct radiation from the platinum coil in any direction met the shield, while a free circulation of vapor was possible. With this shield the thermometer read $0.02^{\circ}$ or $0.03^{\circ}$ lower than when inclosed in the adequate shields previously mentioned. 
TABLE 3.-Comparisons of Shields in Gas-Heated Apparatus

(a) IRON SHIELDS

\begin{tabular}{|c|c|c|c|c|c|c|c|}
\hline Date & $\begin{array}{c}\text { Obser- } \\
\text { vation } \\
\text { num- } \\
\text { ber }\end{array}$ & $\begin{array}{c}\text { Ther- } \\
\text { mome- } \\
\text { ter } \\
\text { num- } \\
\text { ber }\end{array}$ & $\begin{array}{c}\text { Tube } \\
\text { inclosing } \\
\text { thermome- } \\
\text { ter }\end{array}$ & $\begin{array}{l}\text { Description of } \\
\text { shield }\end{array}$ & $P t_{760}$ & $\begin{array}{c}\text { Lower- } \\
\text { ing of } \\
P t 760\end{array}$ & Remarks \\
\hline & & & & & Degrees & Degrees & \\
\hline Nov. $\quad 2,1915$ & 1 & $\mathrm{C}_{26}$ & Porcelain & Cone.................. & 421.65 & 0.00 & Average for $C_{26}, 421.65$ \\
\hline Nov. 8,1915 & 2 & $\mathrm{C}_{27}$ & ...do....... & Umbrella and cone.. & 421.72 & .00 & \\
\hline Nov. 9,1915 & 3 & $\mathrm{C}_{27}$ & Glass.. & .....do............... & 421.73 & -.01 & \\
\hline Nov. 23,1915 & 4 & $\mathrm{C}_{27}$ & ...do........ & ....do.............. & 421.70 & +.02 & \\
\hline Jan. $\quad 4,1916$ & 5 & $\mathrm{C}_{27}$ & ...do........ & ..... do ............... & 421.69 & +.03 & \\
\hline Mar. 9, 1916 & 6 & $\mathrm{C}_{27}$ & Porcelain & .....do.............. & 421.72 & .00 & \\
\hline Apr. 24,1916 & 7 & $\mathrm{C}_{27}$ & ...do...... & .....do............... & 421.73 & +.01 & \\
\hline May 1,1916 & 8 & $\mathrm{C}_{27}$ & ...do... & .....do.............. & 421.73 & +.01 & \\
\hline Nov. 9,1915 & 9 & $\mathrm{C}_{27}$ & Glass.. & $\begin{array}{l}\text { Umbrella, cone, and } \\
\text { disk. }\end{array}$ & 421.69 & +.03 & Reading unsteady. \\
\hline Nov. 10,1915 & 10 & $\mathrm{C}_{27}$ & ...do... & $\begin{array}{l}\text { Umbrella and cylin- } \\
\text { der. }\end{array}$ & 421.72 & .00 & \\
\hline Nov. 12,1915 & 11 & $\mathrm{C}_{27}$ & $\ldots$ do.... & ....do............... & 421.72 & .00 & \\
\hline Do......... & 12 & $\mathrm{C}_{27}$ & ...do...... & . . . do do............. & 421.75 & -.03 & \\
\hline May 26, 1916 & 13 & $\mathrm{C}_{27}$ & Porcelain & .... do............... & 421.73 & -.01 & \\
\hline June 20,1916 & 14 & $\mathrm{C}_{27}$ & ...do....... & ....do.............. & 421.73 & -.01 & \\
\hline Jan. $\quad 5,1916$ & 15 & $\mathrm{C}_{27}$ & Glass...... & $\begin{array}{l}\text { Umbrella and small- } \\
\text { er cylinder, } 23 \mathrm{~mm} \\
\text { diameter. }\end{array}$ & 421.71 & +.01 & \\
\hline Nov. 12,1915 & 16 & $\mathrm{C}_{27}$ & ...do.. & $\begin{array}{l}\text { Umbrella, cylinder, } \\
\text { and disk. }\end{array}$ & 421.73 & -.01 & \\
\hline Nov. 16,1915 & 17 & $\mathrm{C}_{27}$ & ...do. & $\ldots .$. do............ & 421.69 & +.03 & Do \\
\hline Jan. $\quad 5,1916$ & 18 & $\mathrm{C}_{27}$ & ...do... & $\begin{array}{l}\text { Umbrella and double } \\
\text { cylinder. }\end{array}$ & 421.74 & -.02 & Average for $\mathrm{C}_{27}, 421.72$ \\
\hline Nov. 4,1915 & 19 & $\mathrm{C}_{28}$ & ...do... & Cone.............. & 421.67 & .00 & \\
\hline Nov. 5,1915 & 20 & $\mathrm{C}_{28}$ & ... do ... & Umbrella and cone.. & 421.68 & -.01 & \\
\hline May 20, 1916 & 21 & $\mathrm{C}_{28}$ & ...do... & $\begin{array}{l}\text { Umbrella and double } \\
\text { cylinder. }\end{array}$ & 421.68 & -.01 & \\
\hline Mar. 9, 1916 & 22 & $\mathrm{C}_{28}$ & ...do... & $\begin{array}{l}\text { Umbrella and cylin- } \\
\text { der. }\end{array}$ & 421.66 & +.01 & \\
\hline Do......... & 23 & $\mathrm{C}_{28}$ & ...do....... & ....do............... & 421.67 & .00 & \\
\hline May 12,1916 & 24 & $\mathrm{C}_{28}$ & ...do...... & $\begin{array}{l}\text { Umbrella and small } \\
\text { cylinder, } 23 \mathrm{~mm} \\
\text { diameter. }\end{array}$ & 421.65 & +.02 & \\
\hline May 20, 1916 & 25 & $\mathrm{C}_{28}$ & ...do....... & .....do................ & 421.66 & +.01 & \\
\hline May 12,1916 & 26 & $\mathrm{C}_{28}$ & ...do....... & $\begin{array}{l}\text { Umbrella and cylin- } \\
\text { der, } 30 \mathrm{~mm} \text { diam- } \\
\text { eter. }\end{array}$ & 421.66 & +.01 & (1) \\
\hline Do......... & 27 & $\mathrm{C}_{28}$ & ...do... & $\begin{array}{l}\text { Umbrella and cylin- } \\
\text { der, 33mm diam- } \\
\text { eter. }\end{array}$ & 421.68 & -.01 & H \\
\hline May 20, 1916 & 28 & $\mathrm{C}_{28}$ & ...do....... & $\begin{array}{l}\text { Umbrella and cylin- } \\
\text { der, } 32 \mathrm{~mm} \text { diam- } \\
\text { ter. }\end{array}$ & 421.68 & -.01 & Average for $C_{28}, 421.67$ \\
\hline
\end{tabular}


TABLE 3-Continued

(b) MODIFIED ALUMINUM SHIELDS

\begin{tabular}{|c|c|c|c|c|c|c|c|}
\hline Date & $\begin{array}{c}\text { Obser- } \\
\text { vation } \\
\text { num- } \\
\text { ber }\end{array}$ & $\begin{array}{l}\text { Ther- } \\
\text { mome- } \\
\text { ter } \\
\text { num- } \\
\text { ber }\end{array}$ & $\begin{array}{c}\text { Tube } \\
\text { inclosing } \\
\text { thermome- } \\
\text { ter }\end{array}$ & $\begin{array}{l}\text { Description of } \\
\text { shield }\end{array}$ & $P t_{760}$ & $\begin{array}{l}\text { Lower- } \\
\text { ing of } \\
P t 760\end{array}$ & Remarks \\
\hline Nov. 9,1915 & 29 & & Glass.... & Double cone and disk & $\begin{array}{l}\text { Degrees } \\
421.70\end{array}$ & $\begin{array}{c}\text { Degrees } \\
+.02\end{array}$ & \\
\hline Nov. 10,1915 & 30 & $\mathrm{C}_{27}$ & ...do....... & $\begin{array}{l}\text { Umbrella and cylin- } \\
\text { inder, blackened } \\
\text { inside. }\end{array}$ & 421.72 & .00 & \\
\hline Do......... & 31 & $\mathrm{C}_{27}$ & ...do... & $\begin{array}{l}\text { Umbrella and cylin- } \\
\text { der, blackened in- } \\
\text { side, and disk. }\end{array}$ & 421.72 & .00 & \\
\hline Do......... & 32 & $\mathrm{C}_{27}$ & ... do ..... & ....do................ & 421.72 & .00 & \\
\hline Nov. 23,1915 & 33 & $\mathrm{C}_{27}$ & ...do... & .....do.............. & 421.73 & -.01 & \\
\hline Jan. $\quad 4,1916$ & 34 & $\mathrm{C}_{27}$ & ...do.... & .....do.............. & 421.70 & +.02 & \\
\hline Nov. 16,1915 & 35 & $\mathrm{C}_{27}$ & ...do.... & $\begin{array}{l}\text { Umbrella and corru- } \\
\text { gated cylinder. }\end{array}$ & 421.71 & +.01 & \\
\hline Do......... & 36 & $\mathrm{C}_{27}$ & ...do... & $\begin{array}{l}\text { Umbrella, corrugated } \\
\text { cylinder, and disk. }\end{array}$ & 421.72 & .00 & \\
\hline
\end{tabular}

(c) MISCELLANEOUS SHIELDS

\begin{tabular}{|c|c|c|c|c|c|c|}
\hline Nov. 10,1915 & 37 & $\mathrm{C}_{27}$ & Glass..... & $\begin{array}{l}\text { Graphite umbrella } \\
\text { and cylinder. }\end{array}$ & 421.73 & -.01 \\
\hline Nov. 16,1915 & 38 & $\mathrm{C}_{27}$ & ...do....... & Asbestos cone....... & 421. 71 & +.01 \\
\hline Do......... & 39 & $\mathrm{C}_{27}$ & & $\begin{array}{l}\text { Asbestos cone and } \\
\text { disk. }\end{array}$ & 421.71 & +.01 \\
\hline Jan. $\quad 3,1916$ & 40 & $\mathrm{C}_{27}$ & ...do... & Callendar Griffiths.: & 421.73 & -.01 \\
\hline
\end{tabular}

(d) BRIGHT ALUMINUM SHIELDS (INADEQUATE SHIELDING)

\begin{tabular}{|c|c|c|c|c|c|c|c|}
\hline Nov. 2,1915 & 41 & $\mathrm{C}_{26}$ & Porcelain. & Cone................ & 421.58 & +.07 & \\
\hline Nov. 6,1915 & 42 & $\mathrm{C}_{27}$ & $\ldots$ do...... & $\begin{array}{l}\text { Umbrella, cone, and } \\
\text { disk. }\end{array}$ & 421.70 & +.02 & \\
\hline Nov. 8,1915 & 43 & $\mathrm{C}_{27}$ & ...do...... & Cone and disk...... & 421.68 & +.04 & \\
\hline Jan. $\quad 4,1916$ & 44 & $\mathrm{C}_{27}$ & Glass..... & $\begin{array}{l}\text { Umbrella and cylin- } \\
\text { der. }\end{array}$ & 421.51 & +.21 & \\
\hline Nov. 8,1915 & 45 & $\mathrm{C}_{27}$ & Porcelain. & $\begin{array}{l}\text { Umbrella, cylinder, } \\
\text { and disk. }\end{array}$ & 421.66 & +.06 & Old, dull shield. \\
\hline Jan. $\quad 5,1916$ & 46 & $\mathrm{C}_{27}$ & ...do...... & $\ldots .$. do $\ldots . . . . . . .$. & 421.60 & +.12 & New bright shield. \\
\hline Nov. 23, 1915 & 47 & $\mathrm{C}_{27}$ & Glass..... & .... do . . . . . . . . . & 421.62 & +.10 & Unsteady. \\
\hline Jan. 4,1916 & 48 & $\mathrm{C}_{27}$ & ...do...... & .....do................ & 421.60 & +.12 & \\
\hline Nov. 23,1915 & 49 & $\mathbf{C}_{27}$ & ...do...... & Complete shield.... & 421. 70 & +.02 & \\
\hline Jan. $\quad 4,1916$ & 50 & $\mathrm{C}_{27}$ & $\ldots$ do....... & .....do............. & 421.69 & +.03 & \\
\hline Nov. 4,1915 & 51 & $\mathrm{C}_{28}$ & ...do...... & 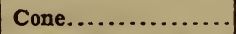 & 421. 48 & +.19 & \\
\hline Nov. 5,1915 & 52 & $\mathrm{C}_{28}$ & ...do...... & Umbrella and cone. & 421.49 & +.18 & \\
\hline Do.......... & 53 & $\mathrm{C}_{28}$ & ...do...... & $\begin{array}{l}\text { Umbrella, cone, and } \\
\text { disk. }\end{array}$ & 421.60 & +.07 & \\
\hline
\end{tabular}

The data for the other aluminum shields, with bright inside surfaces, show that the temperature attained by a thermometer inclosed in such a shield depends upon the form of the shield, 
primarily upon the extent to which the shield forms a complete inclosure, upon the extent to which the interior of the shield has become dull or blackened, and also upon the material (transparency) of the protecting tube of the thermometer. The readings obtained range from $0.2^{\circ}$ low, taken with a simple cone on a glassinclosed theremometer, to $0.02^{\circ}$ low, taken with a nearly closed shield on a porcelain-inclosed thermometer. The extreme lowerings found were $0.2^{\circ}$ for a glass-inclosed thermometer and $0.1^{\circ}$ for a porcelain-inclosed thermometer.

Inadequate shielding is also usually accompanied by considerable variations in temperature, sometimes amounting to $0.1^{\circ}$, when the thermometer is displaced vertically, but the absence of such variation is not necessarily proof of adequate shielding. It may also be remarked in passing that the absence of such variations does not prove that there is no superheating of the vapor, as in one instance constant temperatures were observed with a displacement of $4 \mathrm{~cm}$ where, owing to insufficient depth of liquid sulphur in the tube, the vapor was superheated about $0.5^{\circ}$.

These results are in the main in agreement with those of Meissner, in so far as they cover the same field. They differ from his in regard to the effectiveness of nearly closed aluminum shields, which, according to our results, are more effective than Meissner found them to be. However, there is agreement on the essential point that no bright aluminum shield is completely effective.

Tight-Fitting Umbrella not Necessary. - In most of the shields used, the hole in the center of the umbrella was made to fit the thermometer tube rather closely. Some observers have recommended using asbestos string tied around the thermometer tube just above the umbrella. This was also tried and found to be unnecessary and on account of its inconvenience is regarded as undesirable. Even entirely omitting the umbrella and using only a cylindrical iron shield open at both ends around the coil produced a lowering of only about $0.05^{\circ}$.

Diameter of Cylindrical Shields.-Two thermometers, $\mathrm{C}_{28}$ and $\mathrm{C}_{22}$, were used, both inclosed in glass tubes having diameters of 7 and $10 \mathrm{~mm}$, respectively, with shields varying in diameter from $1.5 \mathrm{~cm}$ greater than the diameter of the thermometer tube to the largest that the boiling tube would conveniently admit. Two series of observations with $\mathrm{C}_{28}$ on different days point to a slightly higher reading with increasing diameter, while observations with $\mathrm{C}_{22}$ point to an opposite tendency. The observed effect is, how- 
ever, too small to be of significance, if the diameter of the shield is not more than about $2.5 \mathrm{~cm}$ greater than that of the thermometer tube, and the thermometer is reasonably concentric with the shield. The fact that good results are obtained with conical shields also indicates that the diameter is of minor importance. It appears, therefore, that shields from 1.5 to $2.5 \mathrm{~cm}$ greater in diameter than the diameter of the thermometer tube are preferable.

Effect of Lower Disk.-An effect which Meissner attributed to the presence of the lower disk, namely, a variable reading during which the resistance varies slowly up and down with apparently various stationary values was noted and investigated. It is true that this effect was noticed most often when the lower disk was present. In order to determine, if possible, whether there existed a critical distance for the disk from the shield edge to give maximum unsteadiness, an iron shield was equipped with a movable disk, the position of which could be controlled from outside the boiling tube. On one day this shield gave perfectly steady readings for all apertures possible; that is, from $2 \mathrm{~mm}$ distance to I I mm between the disk and the edge of the shield. A few days later the use of this same shield at an aperture of $5 \mathrm{~mm}$ was accompanied by fluctuations amounting to $0.01^{\circ}$. In any case, only under extreme conditions, such as raising the thermometer until the top of the shield reached the line of condensation, were fluctuations of $0.05^{\circ}$ noted. When the sulphur was boiling vigorously with a high and sharp condensation line, shields with lower disks gave as steady readings as when the disks were absent. Also continued boiling sometimes caused waverings to disappear and the readings to become steady, as noted by Meissner.

It might be supposed that fluctuations amounting to $0.0 \mathrm{I}^{\circ}$ or $0.02^{\circ}$ are of no serious consequence, and that the reliability of the results is limited only by the accuracy with which the resistance can be determined. Several observations, however, substantiate the conclusion that the reading when unsteady to the extent of $0.01^{\circ}$ only is probably considerably too low, as shown by comparing the steady readings numbered 3 and 16 in Table 3 with unsteady readings numbered 9 and $\mathrm{I} 7$ which were obtained, respectively, with the same shields. The lower disk was abandoned on iron shields since there is a tendency for unsteady, and hence uncertain, readings.

Effect of Omitting Shield.-A thermometer protected only by an umbrella above the coil, assumed temperatures from $0.5^{\circ}$ to $3^{\circ}$ below the temperature assumed by a shielded thermometer, the 
lowering depending upon the height of the coil above the liquid sulphur. The results of similar experiments previously reported indicate that the thermometer under such circumstances reads low by a fairly definite amount, although it might be expected that the temperature assumed by the thermometer would depend upon a large number of factors, such as depth of immersion in the vapor, temperature to which the insulation of the bath has become heated, etc.

Temperature of Shield.-Apart from the effect of the shield upon the temperature assumed by the thermometer, it is of some interest to determine the temperature of the shield itself. If the thermometer be inclosed in a long, close-fitting, closed-end metal tube, the thermometer coil should assume the temperature of the tube, and the tube although differing in form perhaps assumes a temperature not differing much from the temperature assumed by a shield. In this way an iron tube with umbrella above was found to have a temperature about $0.15^{\circ}$ lower than that assumed by an adequately shielded thermometer, while an aluminum tube assumed a temperature only about $0.0 r^{\circ}$ lower. Without the umbrella the iron tube had a temperature about $0.3^{\circ}$ lower and the aluminum shield a temperature about $0.04^{\circ}$ lower than that assumed by a shielded thermometer.

The higher temperature assumed by the externally polished aluminum shield might have been predicted from theoretical considerations, since the aluminum is a poor radiator. It would appear that the best single shield would have a polished exterior and blackened interior, but we have not recommended the adoption of such a shield to the exclusion of other forms because of the difficulty of preparing such shields, and because observation of the temperature of the thermometer inclosed in such a shield shows that the advantage is purely a theoretical one.

Preferred Type of Shield.-From the result of the experimental work described we have come to the conclusion that, in general, the best type of shield is a simple sheet-iron cylinder from 1.5 to $2.5 \mathrm{~cm}$ larger in diameter than the thermometer tube and $4 \mathrm{~cm}$ or more longer than the coil, open below and with an umbrella above. This umbrella should fit the thermometer tube closely and extend beyond the edge of the cylinder, leaving a space $5 \mathrm{~mm}$ to $1 \mathrm{~cm}$ high between umbrella and cylinder for circulation of the vapor. For the material of the shield sheet iron is preferred in general. The main objection to the iron shield seems to be that the sulphur attacks the iron and forms considerable scale, as a 
result of which the iron is consumed and the bath discolored, although without affecting the temperature of the boiling point. Practically all the loose scale is formed when the shield is withdrawn from the bath, however, when the sulphur takes fire spontaneously, so that only a small amount of scale need be left in the boiling tube if care is taken. The life of the iron shield is longer than might be expected. One in particular that had been used a dozen times did not appear appreciably thinner than when first made. This objection to the iron shield is not a serious matter in view of the high and consistent readings obtained with it.

It is possible that the slightly higher temperature $\left(0.0{ }^{\circ}\right.$ or at most $0.02^{\circ}$ ) obtained with the double iron shields may not be attributable entirely to experimental error, and that the use of a single shield will result in slightly low readings. The difference is so small, however, that it seems desirable to standardize the single shield for use in the sulphur boiling point apparatus, in the interest of simplicity. It should be noted that in the electrically heated apparatus this difference was not found. (See Table 4.)

In cases where the iron is objectionable, aluminum, blackened on the inside, may be substituted, and in case it is desirable to introduce nothing but aluminum into the bath, a corrugated aluminum shield is satisfactory, although it requires more time to make. Once made, it is perhaps the most satisfactory of any. Any of the three shields mentioned have been shown to satisfy sufficiently well the following criteria of effective shielding:

(I) The reading must not change more than $0.02^{\circ}$ upon moving the thermometer with the shield up and down in the vapor column for at least $6 \mathrm{~cm}$; for example, from 6 to $12 \mathrm{~cm}$ above the liquid surface.

(2) The reading must be steady; if fluctuations amounting to even $0.0 I^{\circ}$ are present, a readjustment should be made.

(3) The readings should be capable of being repeated from day to day to within $0.03^{\circ}$.

(4) The use of the shield should lead to the same value of $\mathrm{Pt}_{760}$ for a given thermometer regardless of the thermometer protecting tube.

(5) The use of the shield must not lead to different readings with age or repeated use.

(6) Doubling the shield-that is, putting a shield within a similar one-should not change the indications of the thermometer.

(7) The use of the shield should lead to as high a reading as would be obtained by using any other form of shield. 


\section{INFLUENCE OF TYPE OF SULPHUR BOILING APPARATUS}

To test for possible effects of differences in methods of heating, in dimensions and in the heat insulation around the tube, several types of boiling apparatus were constructed and experiments were made to determine the effects of various types of insulation around the boiling tube.

An electrically heated boiling apparatus was built along the lines of the one used by Meissner and described in his paper, the main difference being that the heating coil did not extend under the boiling tube but was wound on an outer porcelain tube, the coil extending upward from a point about on a level with the bottom of the sulphur-containing tube for a distance of about $6 \mathrm{~cm}$. The bottom of the porcelain tube which extended somewhat below the heating coil was closed with asbestos board. An auxiliary heating coil was wound on the upper part of the porcelain tube to hasten the boiling, but was disconnected at least half an hour before observing. The porcelain tube was $30 \mathrm{~cm}$ long, the inner diameter being about $4 \mathrm{~mm}$ greater than the outer diameter of the boiling tube, and thus a small air space was left between the two similar to that shown in Meissner's drawing. This apparatus proved very effective in heating up quickly on about 400 watts, and readings taken on different days were about as consistent as those observed with the gas-heated apparatus.

Nine observations were taken in this apparatus with two thermometers, $\mathrm{C}_{27}$ and $\mathrm{C}_{28}$, the former having a glazed porcelain tube and the latter a glass tube. Comparing these observations which are shown in Table 4 with those made in the gas-heated apparatus, using adequate shields in both cases, $\mathrm{C}_{27}$ gives a value for electric heating $0.01^{\circ}$ higher than for gas heating, and $\mathrm{C}_{28}$ gives a value for electric heating $0.03^{\circ}$ higher than for gas heating. The readings were remarkably constant for displacements of the thermometers up and down for a distance of more than ro $\mathrm{cm}$, the usual variation not exceeding $0.01^{\circ}$. In this type of boiling apparatus there is a possibility that the vapor may be superheated owing to conduction up the porcelain tube, or to convection of highly heated air in the space between the porcelain tube and the boiling tube.

Through the kindness of Messrs. Day and Sosman, the electrically heated apparatus was made available in which their direct determination of the sulphur boiling point by the gas thermometer was carried out. The boiling tube of this apparatus is $7 \mathrm{I} \mathrm{mm}$ internal 
diameter, while that of the specially constructed apparatus above described is $42 \mathrm{~mm}$. A direct comparison of the two was made by interchanging thermometer $\mathrm{C}_{28}$ from one to the other, resulting in a value for the large tube about $0.03^{\circ}$ lower than for the small tube. The temperature observed in the large tube was therefore the same as that observed in the gas-heated apparatus previously described.

TABLE 4.-Observations with Electrically Heated Sulphur Boiling Apparatus

(a) MEISSNER TYPE

\begin{tabular}{|c|c|c|c|c|c|}
\hline Date & $\begin{array}{l}\text { Ther- } \\
\text { mometer } \\
\text { number }\end{array}$ & $\begin{array}{l}\text { Tube in- } \\
\text { closing } \\
\text { thermom- } \\
\text { eter }\end{array}$ & Type of shield & $P t_{760}$ & Remarks \\
\hline Mar. 4, 1916 & $\mathrm{C}_{27}$ & Porcelain & Umbrella and iron cone....... & $421.72_{5}$ & \\
\hline Mar. 9, 1916 & $\mathrm{C}_{27}$ & ...do........ & 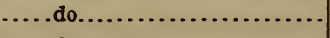 & 421.75 & \\
\hline Do....... & $\mathrm{C}_{21}$ & ... do....... & .....do......................... & 421.735 & \\
\hline Mar. 4, 1916 & $\mathrm{C}_{27}$ & ...do....... & Callendar Griffiths........... & $421.73_{5}$ & \\
\hline June 2,1916 & $\mathrm{C}_{27}$ & ...do....... & Umbrella and iron cylinder... & 421.72 & Average for $C_{27} 421.73 . a$ \\
\hline Mar. 9, 1916 & $\mathrm{C}_{28}$ & Glass..... & .....do........................ & 421.70 & \\
\hline Do....... & $\mathrm{C}_{28}$ & ...do....... & ....do......................... & 421.69 & \\
\hline Mar. 20, 1916 & $\mathrm{C}_{28}$ & ...do........ & ....do...................... & 421.70 & \\
\hline Mar. 6, 1916 & $\mathrm{C}_{28}$ & ...do........ & $\begin{array}{l}\text { Umbrella and double iron } \\
\text { cylinder. }\end{array}$ & 421.70 & Average for $C_{28} 421.70 . b$ \\
\hline
\end{tabular}

(b) DAY AND SOSMAN BOILING TUBE

\begin{tabular}{l|l|l|l|l|}
\hline Mar. 20,1916 & $\mathrm{C}_{28}$ & Glass...... & Umbrella and iron cylinder... & b421.67 \\
\hline
\end{tabular}

a Average for gas-heated apparatus is $42 \mathrm{r} .72$.

b Average for gas-heated apparatus is $42 r .67$.

A tube of small diameter (25 mm internal) was also used as a boiling tube. It was heated with a gas burner and insulated with sheet asbestos. Measurements in this tube indicated superheating of the vapor and considerable differences of temperature at different heights in the tube.

Effect of Surroundings of Tube.-In order to determine to what extent the heat insulation and the character of the surface next to the boiling tube, whether this surface be a good or a poor reflector, might influence the reading of the thermometer, a $70 \mathrm{~cm}$ boiling tube was used in a short jacket, leaving about $30 \mathrm{~cm}$ of the tube extending out into the air. By using a very large flame, it was possible to raise the condensation line high enough to obtain a boiling-point observation in that portion of the tube surrounded only by the air. Boiling-point observations were made under this condition and with the tube surrounded with sheet iron, nickel foil, and thin sheet asbestos. The results are given in Table 5 . 
TABLE 5.-Effect of Surroundings of Boiling Tube Upon Indications of Thermometer $\mathrm{C}_{27}$ with Porcelain Inclosing Tube Shielded with Iron Umbrella and Cylinder

\begin{tabular}{|c|c|}
\hline Material surrounding boiling tube & $P t_{750}$ \\
\hline Air.............. & 421.64 \\
\hline Sheet iron................. & 421.68 \\
\hline Nickel foil.................. & 421.71 \\
\hline 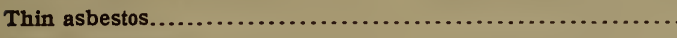 & 421.72 \\
\hline Thick insulation........................... & 421. 72 \\
\hline
\end{tabular}

From the two sets of experiments last described it appears that it would be well to set a lower limit, say $4 \mathrm{~cm}$, to the diameter of the tube in the standard form of boiling apparatus. While it is necessary to provide some insulation for the tube it is evident that a very small amount is sufficient and that the amount used will be dictated by considerations of efficiency.

\section{PURITY OF SULPHUR}

Small known quantities of arsenic and selenium were added to boiling pure sulphur and the boiling point observed in the usual way after each such addition. These materials were selected as being the most probable impurities occuring in ordinary sulphur and which might be expected to affect the boiling point. The results are given in Table 6.

TABLE 6.-Effect of Added Impurities on the Boiling Point of Sulphur

\begin{tabular}{|c|c|}
\hline Condition of sulphur & $\begin{array}{c}\text { Observed } \\
P_{t_{7 \infty}}\end{array}$ \\
\hline Pure......................................... & 421. 73 \\
\hline 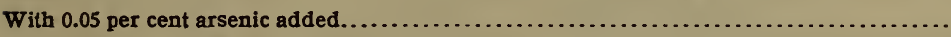 & 421. 73 \\
\hline 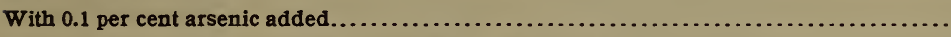 & 421. 75 \\
\hline With 0.05 per cent selenium added (plus the 0.1 per cent arsenic) $\ldots \ldots \ldots \ldots \ldots \ldots$ & 421.81 \\
\hline With 0.1 per cent selenium added (plus the 0.1 per cent arsenic)................. & 421.82 \\
\hline
\end{tabular}

It is evident that selenium, even in small amounts, would be objectionable. All previous experience indicates, however, that such impurities are not likely to be found in purified sulphur. This is further confirmed by the fact that the boiling point of a sample of crude sulphur, from Louisiana, was found to be not over $0 . \mathrm{oI}^{\circ}$ higher than that of the purified sulphur used regularly. The crude sulphur was part of a specimen exhibited in the local office of the Southern Railway Co. and was supplied through the courtesy of their local representative. 


\section{THE RELATION BETWEEN THE VAPOR PRESSURE OF SULPHUR AND} TEMPERATURE

The excellent agreement between the results obtained by Holborn and Henning and by Harker and Sexton might be taken to indicate that any repetition of their work would be superfluous. However, in the present investigation an extended comparison of shields was made during a considerable time interval which involved a range of barometric pressure of 747 to $763 \mathrm{~mm}$, and an equation was necessary which would represent the pressuretemperature relation of sulphur vapor to an accuracy of the order of $0.01^{\circ}$. An examination of Holborn and Henning's data indicated that the excellent agreement of the two sets of observations might have been to some extent, at least, fortuitous, and this, together with the fact that Harker and Sexton's data could not be obtained at all, made it appear desirable to redetermine the relation. The present work gave results in agreement with the older formulas, but a considerably higher degree of precision was attained in the measurements.

The pressure-control apparatus is shown in Fig. 3. The boiling tube was closed by a rubber stopper protected from the heat and from contact with the sulphur vapor by a disk of asbestos. Connection was made with $8 \mathrm{~mm}$ internal diameter tubing through a trap of 2 liters' capacity to the water manometer and to the pressure regulator. The manometer was made of II $\mathrm{mm}$ internal diameter glass tubing and was equipped with mirror and millimeter scale for reading menisci. The pressure regulator was an ordinary 5 cubic foot meter prover with water seal. This proved admirable for pressure control, since it took up any fluctuations of pressure. By means of levers and weights any desired pressure in the given range could be easily produced and maintained regardless of changes in temperature, etc. Simultaneous readings were made of the thermometer, manometer, and barometer.

In each series of observations readings were first taken at one or two pressures very near to $760 \mathrm{~mm}$, then the pressure was increased (or decreased) step by step to the highest (or lowest) attainable with the apparatus, then changed step by step to obtain points intermediate between these previously observed, until the pressure of $760 \mathrm{~mm}$ was again obtained. Further observations at pressures below (or above) $760 \mathrm{~mm}$ were then made. In computing the pressures account was taken of the density of the water in the manometer, the expansion of the manometer scale, and of the 


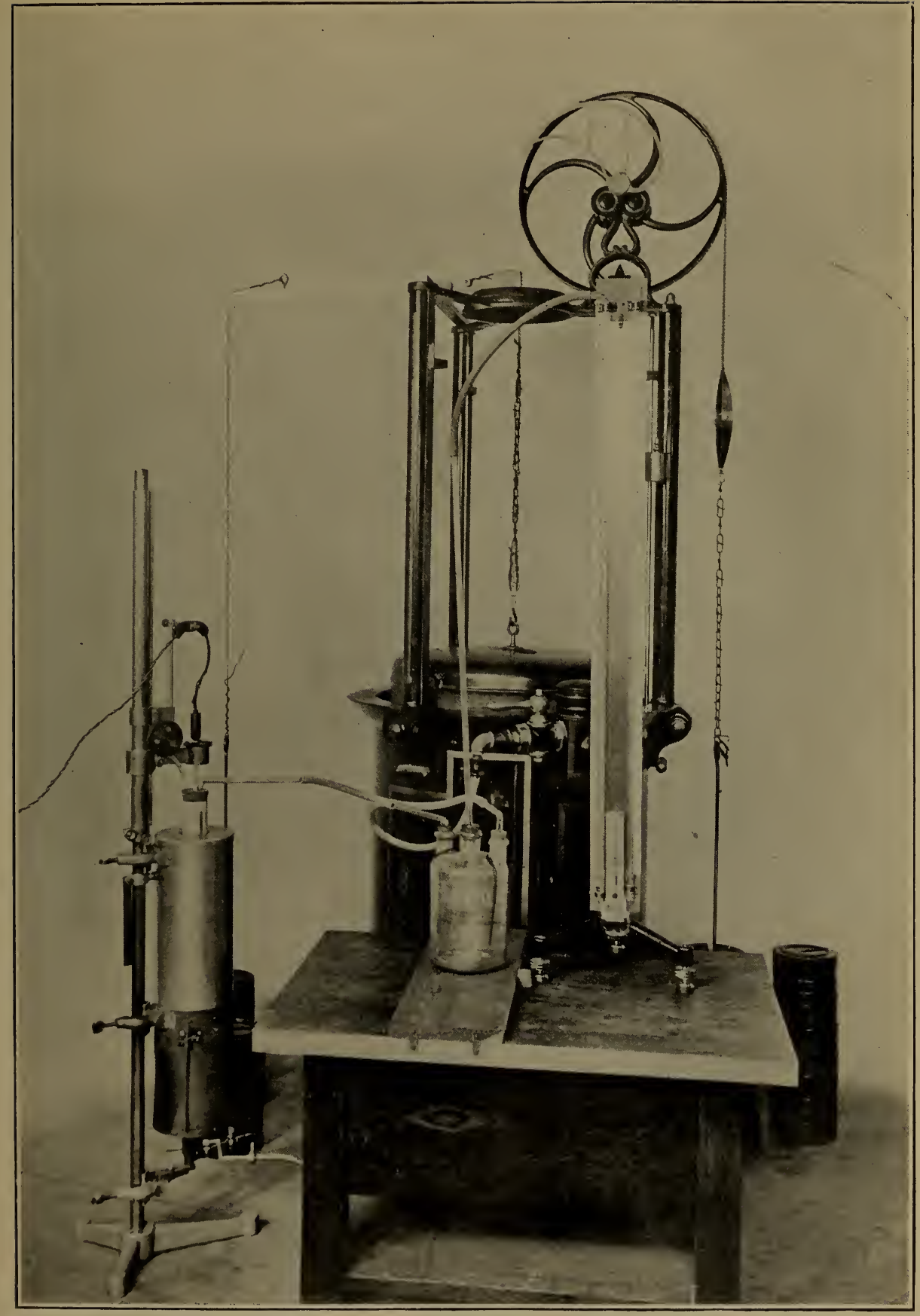

FIG. 3.-Apparatus for varying and measuring pressure of boiling sulphur 
differences in level between the thermometer in the sulphur vapor, the water menisci, and the barometer, in addition to the usual barometric corrections. From the considerable number of observations at pressures near $760 \mathrm{~mm}$ a value of $\delta$ was computed, and in this way the curve was made to pass through the point $t=444^{\circ} .6 p=760 \mathrm{~mm}$. This method of computation might involve the use of a value of $\delta$ differing by one or two units in the third decimal place from the best value of $\delta$ for that thermometer, but insured the agreement of observed and calculated values for normal pressure.

Three series of observations were made and two thermometers were used. All of the observed points are reproduced in Fig. 4, in

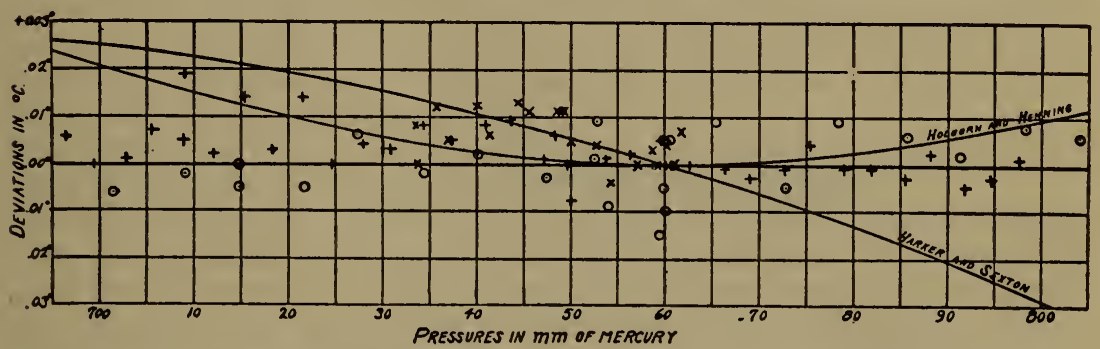

FIG. 4.-Observed minus calculated values of temperature plotted against pressure

$X$ Observations with thermometer $\mathrm{C}_{27}, \mathrm{May} 26$, r916.

+ Observations with thermometer $\mathrm{C}_{27}$, June 20 , I916.

- Observations with thermometer $\mathrm{C}_{22}$, June 23, rgr6.

Positive ordinates indicate higher temperatures than those calculated from the equation.

$t=444^{\circ} 60+0.0910(p-760)-0.000049(p-760)^{2}$ (Mueller and Burgess).

Other equations:

$t=t_{760}+0.0910(p-760)-0.000043(p-760)^{2}$ (Holborn and Henning).

$t=t_{760}+0.0904(p-760)-0.000052(p-760)^{2}$ (Harker and Sexton).

which the deviations of the observed temperatures from those calculated by means of the equation

$$
t=t_{780}+0.0910(p-760)-0.000049(p-760)^{2}
$$

which was found to represent the observations, are plotted against the pressure. The deviations of Holborn and Henning's equation and of Harper and Sexton's equation from the above equation are also shown in Fig. 4.

\section{SUMMARY}

The importance of the sulphur boiling point as defining a standard temperature and the necessity of obtaining further evidence upon certain questions concerning the effect of experimental conditions upon the results obtained in its use, are considered. 
The work of Meissner, which showed that the reflecting power of the inner surface of a radiation shield may have a considerable effect upon the temperature assumed by a resistance thermometer in the sulphur boiling apparatus has been confirmed and extended. A number of types of shields were found to be satisfactory.

The influence of the type of boiling apparatus upon the observed temperature was found to be very small.

The effect of certain impurities in the sulphur upon the observed boiling point was investigated.

The change of vapor pressure with temperature over the range of pressures from 700 to $800 \mathrm{~mm}$ was redetermined. 


\section{A P P E N D I X}

\section{PROPOSED STANDARDIZATION OF THE SULPHUR BOILING POINT}

All experimental work published has been drawn upon in preparation of these specifications. The specifications relate to apparatus and procedure suitable for the standardization primarily of resistance thermometers and thermocouples, and it was therefore considered permissible to limit the type of apparatus somewhat closely. The aim has been to impose conditions which are sufficient to insure that the thermometer shall assume a definite temperature, dependent only upon the pressure, when placed in the apparatus, and the question as to whether these conditions are really necessary has received only secondary consideration. Thus the question as to the temperature attained in tubes larger or smaller than those specified need not be considered. It may further be supposed that the thermometer or couple will be mounted in a protecting tube or sheath, and that the diameter of such a tube or width of the sheath will be less than $2 \mathrm{~cm}$.

The specifications relate to the following matters: (r) Boiling apparatus, (2) purity of sulphur, (3) radiation shield, (4) procedure, and (5) computations.

(x) Boiling Apparatus. - The boiling tube is of glass, fused silica or similar material, and has an internal diameter of not less than 4 nor more than $6 \mathrm{~cm}$. The length must be such that the length of the vapor column measured from the surface of the liquid sulphur to the level of the top of the insulating material surrounding the tube shall exceed the length of the thermometer coil by at least $20 \mathrm{~cm} .{ }^{11}$ Heating is by any suitable heater at the bottom of the tube, and the arrangement must be such that the heating element, and all conducting material in contact with it, terminate at least $4 \mathrm{~cm}$ below the level of the liquid sulphur. If a flame is allowed to impinge directly on the tube, the heat insulation must extend at least $4 \mathrm{~cm}$ below the level of the liquid sulphur. There should be a ring of insulating material above the heater, fitting the tube closely, to prevent superheating of the vapor by convection currents outside the tube. Above the heater the tube is surrounded with insulating material, not necessarily in contact with it, and of such character as to provide heat insulation equivalent to a thickness of not less than $\mathrm{I} \mathrm{cm}$ of asbestos. The length of this insulation has already been specified. Any device used to close the top of the boiling tube must allow a free opening for equalization of pressure.

(2) Purity of Sulphur.-The sulphur should contain not over 0.02 per cent of impurities. It should be tested to determine whether selenium is present.

(3) Radiation Shield.-The radiation shield consists of a cylinder open at both ends and provided with a conical umbrella above. The cylindrical part is to be 1.5 to $2.5 \mathrm{~cm}$ larger in diameter than the protecting tube of the thermometer, and at least I $\mathrm{cm}$ smaller than the inside diameter of the boiling tube. The cylinder should extend $1.5 \mathrm{~cm}$ or more beyond the coil at each end. The umbrella should fit the thermometer tube closely, should overhang the cylinder, and be separated from the latter by a space 0.5 to $\mathrm{r} \mathrm{cm}$ high. The inner surface of the cylinder must be a poor reflector, such as sheet iron, blackened aluminum, asbestos, or a deeply corrugated surface.

11 This length was arrived at as follows: The minimum distance from the liquid surface to the bottom of the shield was taken as $6 \mathrm{~cm}$, excess of length of shield over length of thermometer coil $6 \mathrm{~cm}$, distance available for displacing thermometer $6 \mathrm{~cm}$, and minimum distance from top of shield to level of top of insulation $2 \mathrm{~cm}$. 
(4) Procedure.-The sulphur is brought to boiling ${ }^{12}$ and the heating is so regulated that the condensation line is sharply defined and is $\mathrm{I} \mathrm{cm}$ or more above the level of the top of the insulating material. The thermometer, inclosed in its shield, is inserted into the vapor, taking care to have the thermometer coil properly located with respect to the shield, and the thermometer and shield centered in the boiling tube. After putting the thermometer into the vapor time must be allowed for the line of condensation again to reach its proper level. Simultaneous readings of the temperature and barometric pressure are then made. In all cases care should be taken to prove that the temperature is not affected by displacing the thermometer 2 or $3 \mathrm{~cm}$ either up or down from its usual position.

(5) Computations.-Temperatures are calculated from the pressure by use of the formula,

$$
T=444: 60+0.0910(p-760)-0.000049(p-760) .^{2}
$$

If necessary, account should be taken of any difference in pressure between the levels at which the thermometer bulb and the open end of the barometer, respectively, are located. Pressures are to be expressed in the equivalent millimeters of mercury at $\circ^{\circ}$ and under standard gravity $(g=980.665)$.

\footnotetext{
12 If the sulphur has been allowed to solidify in the bottom of the tube, it must be melted from the top downward to avoid breaking the tube. A better procedure is that recommended by Rothe (Z. S. für Instrk., 23, p. 366,1903$)$, viz, on completing work with the apparatus it is turned so that the tube makes an angle of $30^{\circ}$ or less with the horizontal, so that the sulphur on solidifying extends along the sides of the tube, in which position it may be melted down with less danger of breaking the tube. Even when the procedure recommended is followed, breakage of tubes may be reduced by carefully melting the sulphur from the top downward over a bunsen burner before applying heat to it in the apparatus.
}

WASHINGTON, January 22, I9I9. 